\title{
Improving Student Skills In Singing Serat Wedatama Pupuh Pangkur Using Snowball Throwing Method In Vocational School
}

\author{
Tri Purwadi ${ }^{1}$, Retno Winarni ${ }^{2}$, Muhammad Rohmadi ${ }^{3}$, Kundharu Saddhono ${ }^{4}$ \\ \{Mdrx36@yahoo.com¹,winarniuns@yahoo.com²,rohmadi_dbe@yahoo.com³, \\ kundharu@uns.ac.id $\left.{ }^{4}\right\}$ \\ 1,2,3,4Universitas Sebelas Maret, Indonesia
}

\begin{abstract}
The purpose of this research is to improve student's achievement in singing tembang macapat serat wedhatama pupuh pangkur. The subject of the research are students grade X Accounting 1 from Vocationak School 6 Surakarta. The research's method used is classroom action research. CAR is an action in teaching students using certain method to solve the problem in the classroom. The teacher or researcher used Snowball Throwing Method to solve the problem faced in the classroom. Preliminary data that the researcher got from the classroom show that the students achievement in singing tembang macapat is very low. The students who get score more than minimal criterion score is only $52 \%$ of the total 36 students. In the first cycle students' score increase from $52 \%$ become $60 \%$. The researcher needs to increase the students' score more. He decided to continue the process into the second cycle.The second cycle shows better than first cycle. There are only two students who get score under KKM. It means that $94 \%$ students got score upper than 75 or more than minimum criterion score. Teaching student using Snowball Throwing method can increase student learning activeness; develop social, and emotional intellectual potential. The Snowball Throwing method can increase students' scores in singing serat wedhatama pupuh pangkur.
\end{abstract}

Keywords: Student's Achievement, Macapat, Snowball Throwing

\section{INTRODUCTION}

Javanese is a part of languages that develop in the country. Javanese has regional characteristics and is one of the riches of Indonesian culture and its existence needs to be preserved. Javanese is a regional characteristic that functions as a means of communication between individuals or groups, especially Javanese.

In daily activities in the classroom, the push factor for teacher using Javanese language is student's lack of Indonesian vocabulary as Javanese is their daily language. Thus, teacher often use some Javanese terms in the learning process. Indeed, it aims at attracting 
student's attention to better understand teacher's explanation in class and the learning process run smoothly. The use of Javanese language brings positive effect for the process of learning. Teacher who teach with Javanese and Indonesian language is more understood by students because not all students understand Indonesian language used by the teacher. Thus, the use of both Javanese and Indonesian language is more effective to deliver information and knowledge to students [1].

Another part of javanese culture is Tembang Macapat. It belongs to Sastra Jawa. Sastra Jawa adalah sebagian kecil dari hasil budaya Jawa. Karya sastra merupakan cermin keadaan sosial budaya tertentu yang menjadikan karya sastra dipakai sebagai materi penting untuk mengungkap suatu budaya lampau yang telah kehilangan jejak [2]. Tembang Macapat is a characteristic of Indonesian culture that has deep philosophical values and beauty when it is sung. Tembang macapat is also enrich with various symbols in it which must be interpreted. Simple words, easy to understand will create metaphysical energy in the reader so that tembang macapat has a meaning and good affect in students's character.

The students' interest in this macapat song was very low. Students did not like it even just to know it. Students prefered contemporary songs. Students prefer listening songs with the dangdut koplo genre, it is a kind of popular songs that can be downloaded from YouTube.

This caused the students' skills in singing tembang macapat to be very low. Even many students had not been able to sing at all. From the observations made by the researchers in class X Accounting 1 of SMK Negeri 6 Surakarta in the academic year 2018/2019 their ability to sing tembang pangkur was still very low. When they were in the class X odd semester in the year 2018/2019 the resercher who is also teacher in this class found that only $52 \%$ of students who were able to reach the minimum criteria for the subject matter of tembang macapat.

At that time the researcher tried to teach students about things related to tembang macapat in general, it was about the kinds of tembang macapat and examples of how to sing it, then he tried to review the values of the lyrics. The researcher got the impression that students were very afraid or ashamed when they were required to try singing a tembang macapat. They were hesitant even reluctant to try even though they had been given an example by the researcher who was also a Javanese language teacher in the class

The researcher realized that a solution must be sought to overcome these problems. The researcher tried to find a method or technique that can make students brave trying to sing the song. Teaching using this method is a condition where students are not depressed and do not feel that they are actually being forced to try. The researcher tries to choose the Snowball Throwing method.

The selection of the Snowball Throwing method is based on several literature studies and studies conducted by several experts. One of the studies which is the basis of reference is the research conducted [4], The research is a classroom action research that has conclusions: 1) Snowball Throwing learning model can increase the speaking courage of class IX B students of SMP Negeri 2 Musuk. 2) The Snowball Throwing learning model can improve the ability to read graphics of class IX B students of SMP Negeri2 Musuk. 3) The Snowball Throwing learning model can increase the courage to speak and the ability to read graphics of class IX B students of SMP Negeri 2 Musuk. Studying bahasa is even more fun.

The advantages of this method include this method can make the players or in this case the students become more active and their ability about memorizing the English vocabulary is more increased because they learn in an enjoyable way, fun in learning with snowball throwing technique brings a real word context into the classroom and enhances students to use 
English in a flexible communicative way, it can make students relax and fun to study, the teaching learning process more attractive, and the teacher can easily teach the vocabulary [5].

Based on some researches and literatures study, the writer then found out about the application of the Snowball Throwing method, whether it was able to improve students' skills in singing tembang macapat serat Wedatama's pupuh pangkur for students in Vocational school.

\section{METHOD}

Problems encountered by writers in the classroom must be resolved immediately. Classroom action research is one alternative to solve the problem. Classroom Action Research (CAR) is a classroom context research that is carried out to solve learning problems faced by teachers, improve quality and learning outcomes and try new things in learning to improve quality and results learning.

From the data of the initial conditions obtained, the researcher in this case the researcher will determine the methods, techniques, or media that can be used to overcome these problems. In this study the researchers used the snowball throwing method to overcome the problem that was faced by the student. The steps in the snowball throwing method will be applied in the form of a lesson plan, then the lesson plan will be used in teaching. At the end of each cycle an assessment is planned as planned in the lesson plan. Reflections and Re-plans continue to be carried out to address students' problems. The number of meetings or cycles needed to be adjusted to increase student scores. In this research, the subjects are students of X Acconting 1 SMK Negeri 6 Surakarta in the even semester year 2018/2019.

\section{RESULT AND DISCUSSION}

The problems that arise in the classroom are the students' skills in singing tembang macapat pupuh pangkur dalam serat wedatama is low. The researcher tries to find a solution to overcome this problem. The researcher chose the Snowball Throwing method as a method of teaching to solve these problems

Snowball Throwing is one of the active learning model which in practice involves many students. Every student is accountable for not only learning material but also explaining it to another student. This is an interactive alternative to discussion and review. This method is helpful for reviewing information, summarizing and verbally expressing facts and information, and interacting with peers [6].

Snowball Throwing Method of learning is a learning method that begins with the formation of a group that represents the head of the group to get the task from the teacher and then each student asks questions that shape like a ball (question paper) and then throws to the other students that each student has to answer the question of ball obtained [7].

Snowballing is one form of discussion that moves students to issue their ideas and thoughts on topics that are taught by teachers [8]. First, convey the topic to be solved. Second, ask the students to answer the issues presented by the teacher. Third, combine the first two groups into larger groups. Students' talk again about the problem given by the teacher. Next, repeat the previous step, combine the two groups into one larger group. Finally, repeat the step until the teacher has enough with students' discussion.

There are several benefits that can be obtained and the Snowball Throwing model includes elements of the game that cause this method to attract students' attention. the Snowball Throwing method has several benefits: 1) increasing student learning activeness; 2) 
developing social, and emotional intellectual potential that exists in students; 3) trainning students to express ideas and feelings.

From the results of several studies indicate that the Snowball Throwing method can improve student learning achievement. The several studies include: Research conducted from the application of learning methods using the Snowball Throwing method has shown an increase in the percentage of completeness of student learning outcomes at the cycle stage[9]. Based on the results of the initial and final tests of the two cycles, it can be concluded that all improvement activities in this teaching have all shown success in giving students an accurate and accurate understanding.

The researcher used the steps in teaching using snowball throwing method which is suggested the steps of snowball throwing method as follows: 1) Each group member works alone to list the ideas or information; 2) Pairs explain their lists to each other and then make combined list; 3) Duplications are eliminated; 4) Pair one and pair two get together and make a new combined list; 5) Duplication are eliminate[10].

the Effectiveness of Snowball Throwing Learning Methods on the Ability to Analyze Religious Values of Novel Munajat Cinta II "shows that the Snowball Throwing method is more effective than the lecture method in learning Bahasa, especially in analyzing religious novel values [11].

The students achievements were important to know their comprehension about the selected reading [12]. The questions for comprehension were always given in each cycle. The average of students ${ }^{\text {ee }}$ achivement from first cycle to third cycle shows the improvement in each cycle; the first cycle is 68.9 , the second cycles is 71.3 , and the third cycle is 77.6. It indicated that the students were easier to understand the text by using the snowballing.

The results of his research entitled "Implementation of Throwing Snowball Method to Improve Speaking Skills Students in Class III Student Development MI UIN Jakarta", concluded that improvement in speaking skills can be seen from the increase in average scores in the first cycle[13].

The result of the research that was done [14] "Using snowball throwing Model to Increase The Speaking Ability of The Second Year Students Of Smp N 21 Pekanbaru" shows that the snowball throwing method can increase students speaking achievement. researcher can conclude that similarity with researcher is use snowball throwing method and the difference between place of research and grade of students.

The application of Snowball Throwing learning model to improve the activity and learning outcomes of students in class X IIS 1 in SMA Brawijaya Smart School, it can be concluded that application of learning model Snowball Throwing can run smoothly and appropriately applied to economic subjects with capital market material and insurance is characterized by the increase from cycle I to cycle II [15].

Research had been done by concluded that the post-test mean score of the students that were taught by using"Snowball Throwing" method was higher than the students that taught conventionally[16]. The post-test mean score of experimental class before getting the treatment was 66.95 and after getting the treatment was $84.95(84.95>66.95)$. It was higher than control group; the post-test mean score was 84.95 . Therefore, it could be said that there was improvement score of pre to post-test of experimental class. The score was increased because the writer used Snowball Throwing as a method in teaching writing procedure text.

In the pre-cycle of this research the student's achievement in singing macapat was low. It happened because the teacher did not give them an opportunity to sing. The activities did by the teacher in learning process only gave the students example of the expression then students try as they can 
In the first cycle, the students score increased but still under the teacher expectation or under minimum criteria. It was happened because the teacher used Snowball Throwing Method which gave the students opportunity to sing. But the problems were the students still did not get enough opportunity to sing because they were divided into big group. The teacher explanation to the leader was not enough clear because of limitation of the time.

In the second cycle, the students score increased significantly. There were only 2 students or 6.25 percents, who got score under minimum criteria. It was happened because the teacher used Snowball Throwing Method with small group, which gave the students opportunity to sing. the students still got enough opportunity to sing because they were divided into small group. The teacher's explanation to the leader was enough clear because she allocate more time in this steps. The collaborator noticed that the teacher did the entire step in lesson plan well. It means that teacher totally used the Snowball Throwing Method in every meeting.

Singing macapat songs requires courage and skill. Students are not only skilled in chanting or memorizing the lyrics and tone, but the courage to sing loud and true. Students need to be encouraged to practice their courage and accuracy in singing the song. Through the snowball throwing method, students can increase their activity, and be able to express their ideas and feelings. From several studies also showed that the snowball throwing method was able to improve student learning outcomes. Snowball throwing is more effective than a number of other methods for use in the classroom.

\section{CONCLUSION}

The Snowball throwing method can solve the problem in singing tembang macapat serat wedatama pupuh pangkur. If it is done in earnest the snowball throwing method is able to improve the process and student's achievement in singing serat wedatama pupuh pangkur in Class X Accounting Students 1 in SMK Negeri 6 Surakarta, in the Even Semester Academic Year 2018/2019. It was happened because the teacher or researcher used small group in applying Snowball Throwing Method. It gave the students opportunity to sing. the students still got enough opportunity to sing because they were divided into small group. The teacher researcher allocated more time explanation to the leader and gave clear enough in this steps.

\section{REFERENCES}

[1] Hidayati, NA., Herman J.W., Retno W., Suyitno. Ritual Animism and Religious on Sura Thanksgiving Ceremony of Samin Jepang Margomulyo Tribe Community. ICIGR. Advances in Social Science, Education and Humanities Research (ASSEHR), vol. 125, Pp. 348-353. 2017.

[1]. Saddhono, Kundharu., \& Muhammad Rohmadi. A Sociolinguistics Study on the Use of the Javanese Language in the Learning Process in Primary Schools in Surakarta, Central Java, Indonesia. International Education Studies; Vol. 7, No. 6; 2014. 2014.

[2]. Widayat A, dan Suwardi. Sejarah Sastra Jawa. Yogyakarta. Fakultas Bahasa dan Seni. Universitas Negeri Yogyakarta. 2005.

[3]. Sukawati, Eda.. Peningkatan Keberanian Berbicara dan Kemampuan Membaca Grafik Melalui Model Pembelajaran Snowball Throwing. Jurnal Kajian Linguistik dan Sastra, Vol 27, No 2, Desember 2015, 96-107. 2015.

[4]. Widayati, Ani. Penelitian Tindakan Kelas. Jurnal Pendidikan Akuntansi Indonesia. Vol. VI No. 1 Hal. 87 - 93. 2008. 
[5]. Aisyah.The Snowball Throwing Technique In Improving Students' Vocabulary.The Internet TESL Journal. 2008.

[6]. Hamdayama,J..Model dan Metode Dalam Pembelajaran. PT.Raja Grafindo Persada. 2014

[7]. Sprenger. Wiring The Brain for Reading.Jossey-Bass. 2013

[8]. Zaini. Strategi Pembelajaran Aktif.Seminar Loka Karya Nasional Pendidikan Biologi. 2009.

[9] Yuliati. Efektifitas Penggunaan Model Kooperatif Tipe Snowball Throwing Untuk Meningkatkan Hasil Belajar Siswa Pada Materi Sistem Pertidaksamaan Linear Di kelas xi-is-2 SMA Negeri 7 Banda Aceh. Jurnal Peluang, Volume 3, Nomor 2, April 2015. 2015.

[10]. Zarei.. Collaborative Techniques.Lambert Academic Publishing. 2012.

[11].Sembiring, Renni Handayani. Efektivitas Metode Pembelajaran Snowball Throwing Terhadap Kemampuan Menganalisis Nilai-Nilai Religius Novel Munajat Cinta II" Karya Taufiqurrahman Al-Azizy Oleh Siswa Kelas XI Madrasah Aliyah Swasta Proyek Univa Medan Tahun Pembelajaran. Asas: Jurnal Sastra. Vol 1, No 1. 2012.

[12]. Sri Wahyuni. The use of Snowballing Strategy in Teaching Reading Literary Texts (Short Stories). Language circle Journal of Language and Literature . Vol. VII/2 April 2013. 2013

[13]. Pelatun, Siti Nurkhoyah. Penerapan metode snowball throwing dalam peningkatan keterampilan berbicara siswa kelas III MI Pembangunan UIN Jakarta.

[14]. Masyihur. Using Snowball Throwing Model To Increase Speaking Ability Of The Second Year Students Of SMP N 21 Pekanbaru. The Internet TESL Journal. 2011

[15]. Zaqiyaturrahmah, Eva. Implementation Of Cooperative Learning Model Snowball Throwing To Increase Activity And Learning Outcomes. Classroom Action Research Journal. Volume 2 Number 2 2018. 87-94. .2018.

[16] Solikha, Khusna Eka Putri. The Effectiveness of "Snowball Throwing" Method In Teaching Writing Procedure Text. Vol. 4 No.2 September 2016 - February 2017 Page 39-53. Dialektika Journal. 2016. 